\title{
Shipping in changing climates
}

DOI:

10.1016/j.marpol.2016.05.033

\section{Document Version}

Accepted author manuscript

Link to publication record in Manchester Research Explorer

\section{Citation for published version (APA):}

Bows-Larkin, A., Smith, T., \& Wrobel, P. (2016). Shipping in changing climates. Marine Policy. https://doi.org/10.1016/j.marpol.2016.05.033

\section{Published in:}

Marine Policy

\section{Citing this paper}

Please note that where the full-text provided on Manchester Research Explorer is the Author Accepted Manuscript or Proof version this may differ from the final Published version. If citing, it is advised that you check and use the publisher's definitive version.

\section{General rights}

Copyright and moral rights for the publications made accessible in the Research Explorer are retained by the authors and/or other copyright owners and it is a condition of accessing publications that users recognise and abide by the legal requirements associated with these rights.

\section{Takedown policy}

If you believe that this document breaches copyright please refer to the University of Manchester's Takedown Procedures [http://man.ac.uk/04Y6Bo] or contact uml.scholarlycommunications@manchester.ac.uk providing relevant details, so we can investigate your claim.

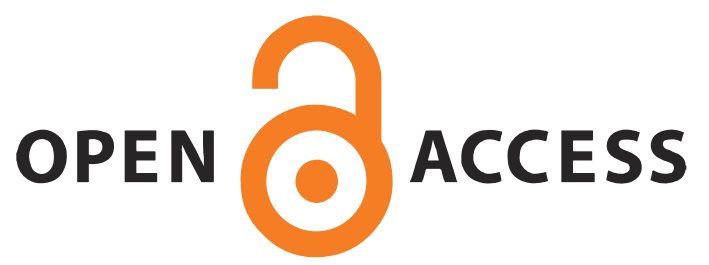




\title{
Shipping in changing climates
}

\author{
Alice Bows-Larkin ${ }^{\mathrm{a}, *}$, Tristan Smith ${ }^{\mathrm{b}}$, Paul Wrobel ${ }^{\mathrm{c}}$ \\ a Tyndall Centre for Climate Change Research; School of Mechanical, Aerospace and Civil Engineering, University of Manchester, United Kingdom \\ ${ }^{\mathrm{b}}$ UCL Energy Institute, United Kingdom \\ c Department of Mechanical Engineering, UCL, United Kingdom
}

\section{A R T I C L E I N F O}

Article history:

Received 26 May 2016

Received in revised form

28 May 2016

Accepted 28 May 2016

\begin{abstract}
A B S T R A C T
The shipping industry faces an uncertain future, as the climate change challenges faced by all sectors become increasingly urgent and apparent. If a quantitative interpretation of the goals laid out in the Paris Agreement is applied, shipping, along with all sectors combusting fossil fuel, faces substantial challenges in order to successfully decarbonise over the coming decades. Targeted at addressing gaps in knowledge and understanding across technical, operational and demand-side changes, this collection of articles presents some of the latest analysis to consider the opportunities available, and barriers to be overcome, to enable shipping's low carbon transition and the sustainability of global trade.
\end{abstract}

(c) 2016 Published by Elsevier Ltd.

\section{Introduction}

Towards the end of 2015, text within the United Nations Framework Convention on Climate Change's proposed new agreement was changing on a regular basis. In particular, whether or not there would be any reference to international shipping (or aviation) within it was highly uncertain. Even before the Paris meeting, this situation sent out mixed messages with regards to the importance of mitigating these growing international emissions. When the draft Paris Agreement was eventually published in full [15], all of the specific wording about international shipping (and aviation) was left out. So where does that leave the mitigation agenda for the international shipping sector?

From a scientific point of view, the arguments remain unchanged. The science underpinning a goal of avoiding an identifiable level of climate change (in terms of global temperature rise with respect to pre-industrial levels) provides a clear steer on the outlook for any sector combusting fossil fuels. More specifically, the goals laid out in Article 2 of the new Paris Agreement which "aims to strengthen the global response to the threat of climate change by holding the increase in the global average temperature to well below $2{ }^{\circ} \mathrm{C}$ above pre-industrial levels and to pursue efforts to limit the temperature increase to $1.5^{\circ} \mathrm{C}$ above pre-industrial levels", requires urgent and concerted mitigation effort across countries and sectors. Furthermore, the text also clearly highlights its "serious concern" that there is a significant gap between the efforts pledged by nations in advance of the Paris meeting, and the

\footnotetext{
* Corresponding author.

E-mail address: alice.bows-larkin@manchester.ac.uk (A. Bows-Larkin).
}

ambition laid out in its Article 2. With the scientific relationship linking the cumulative emissions of carbon dioxide with future temperature change a well accepted one [8], this leaves little room to manoeuvre for any sector emitting $\mathrm{CO}_{2}$ - rapid, deep and urgent global decarbonisation is the order of the day. How to deliver such a tall order is a matter that the articles within this special issue are aiming, in various ways, to explore.

\section{Exploring decarbonisation options}

\subsection{Deep decarbonisation of shipping: barriers and opportunities}

The absence of a coherent policy framework aligned with the ambition of the Paris Agreement is one explanation for slow uptake of many of shipping's deep decarbonisation technology options. However, it is also useful to consider and anticipate some of the barriers that may be preventing greater levels of uptake of emission reducing technologies now, and that may further hinder, or increase the cost of, deep decarbonisation in the future. Suárez de la Fuente et al. [14] describe how waste heat recovery systems can reduce energy demand, but also potentially conflict with existing safety regulations. These regulations are a product of the historic design and operation of ships, yet both have been superseded by the now commonplace use of unmanned machinery spaces, rendering the regulations less justified. Whilst other important low carbon technologies may have less easily resolved safety conflicts, this is nonetheless an important reminder of the wide-ranging regulatory landscape that needs to be complied with when moving towards a low carbon shipping system. Potential 
barriers to deep decarbonisation due to existing policy are also identified in [13] but with a focus on the ferry sector in the EU. The paper draws attention to the structuring of public-private sector interaction and its potential for negative consequences for energy efficiency. Connected to this are issues around the monitoring and verification of measures that successfully improve energy efficiency. With such measurement a current focus of the policy debate, Deligiannis [4] topically presents a new ship performance indicator that compares the chemical energy of the consumed fuel with the propulsion effect. The indicator can be derived from parameters listed in daily sailing reports, thereby providing a relatively simple measure of energy performance.

Decarbonisation on the scale and timeframe implied by the Paris Agreement will necessitate going well beyond incremental efficiency gains, and even beyond what technology may have to offer. An inevitable question asked when engaging stakeholders in discussion of shipping's decarbonisation is "how could this be done? "Whilst this special issue is not focused on the identification and analysis of decarbonisation pathways themselves, a number of papers suggest promising technology and operational options. These include a concerted effort for slow (or even ultraslow) steaming [10], the use of waste heat recovery as mentioned previously [14], and the use of wind-assistance technology [10,12]. In some instances there are synergies that can occur (e.g. between wind-assistance and slow-steaming, [3]), but these papers also highlight challenges and opportunities for policy to assist in enabling the potential solutions to reach maturity and scale deployment. Rehmatulla et al. [12] highlights the sensitivity of the industrial ecosystem and the significant "valley of death" faced by the wind-assistance technology developers. Whilst in this instance this analysis is applied to a particular example of a low carbon technology, the paper highlights challenges that can be found in many of the areas from which innovative solutions for the reduction of shipping's emissions will need to be derived.

Beyond challenges in the development of policy to cost-effectively achieve deep decarbonisation in shipping directly, there are interactions with other sectors and systems. Gilbert et al. [7] explores the breakdown of $\mathrm{CO}_{2}$ emissions from different stages of a ship's lifecycle, highlighting the significance of embodied $\mathrm{CO}_{2}$ emissions in the sector, as well as the magnitude of emission reduction (the opportunity) that could be realised if steps to decarbonise shipping could be aligned to wider system material efficiency endeavours. Similarly, Kotrikla et al. [9] shows that the use of shore-side electricity to reduce emissions from ship's machinery in ports can be of low net benefit unless the land-based power generation is decarbonised at the same time. Both of these papers are important reminders that the shipping industry does not exist in isolation. Therefore managing its decarbonisation must happen in close coordination with the associated decarbonisation of global manufacturing and energy systems.

\subsection{From local to global}

A topic that is commonly debated when exploring mitigation in a sector than transcends national boundaries is the appropriate scale of governance and responsibility. One configuration to achieve decarbonisation would be a global and enforced greenhouse gas emissions cap, within which fungible mechanisms at a range of geographical or operational (e.g. sectoral) scales could deliver on an overall global target. A global greenhouse gas trading scheme that the shipping sector is a part of would be an attractive mechanism for decarbonisation in this context, particularly given the challenges in apportioning responsibility for shipping emissions to nations or other sub-global scales [6]. However, in a world in which no such comprehensive global framework exists, alternative ways to achieve "well below" $2{ }^{\circ} \mathrm{C}$ are required. What are the practical options, for shipping?
Policies and opportunities at a national or 'port-state' scale are wide ranging, and may also arise driven by other needs (reducing local pollution in ports, or dependency on fossil fuel imports, for instance). As mentioned previously, Kotrikla et al.'s [9] analysis explores one such opportunity - namely the use of cold-ironing supported by renewable electricity production - in an Aegean island port. Not limited to tackling $\mathrm{CO}_{2}$ however, the provision of renewable and shore-side electricity for berthing ships has the cobenefit of reducing other pollution such as $\mathrm{PM}_{10}$. Whilst such a system is shown to deliver on its objectives, the authors admit that the $\mathrm{CO}_{2}$ from ships when they are docked is only a small element of the overall emissions ships produce, demonstrating that dividing up responsibility for regulation of emissions also has its challenges.

Drivers for decarbonising local sea transport in the small island communities of Fiji are also closely aligned with the wider development agenda, and include the current strong reliance on fossil fuels to deliver and support basic islanders' needs. Newell et al. and Bola $[2,11]$ both attend to this issue from different perspectives, highlighting a strong demand-pull for innovation towards decarbonised propulsion systems. However, as we saw in Gilbert et al. [7] and Rehmatulla et al. [13], without up-front financial provision to drive innovation, or demonstrate the viability of a disruptive technology, progress will likely remain slow. A further perspective on 'local' initiatives is supplied by Fenton [5], who explores the role of port cities and municipal networks in curbing greenhouse gas emissions - both on land and sea. While Fenton highlights that there continue to be many barriers preventing a more coordinated port-city approach to decarbonisation, he identifies several areas ripe for exploitation including more active engagement by cities in ports' strategic work around climate mitigation and a greater involvement of key city-focused stakeholders within port-focused initiatives. One advantage of Fenton's port cities perspective is the ability to look beyond direct maritime emissions, as such an approach would also encompass land-based freight - a source of growing greenhouse gas emissions often identified by stakeholders within the shipping industry as a carbon leakage risk of maritime-centric mitigation efforts.

Broader still, the resilience of shipping infrastructure and trade to future climate impacts (for example sea level rise or changes in weather patterns), has implications for the sector both globally and locally. Information and tools that enable local actors to make decisions in the face of unprecedented uncertainties associated with climate change will be essential to maintain a buoyant but low-carbon shipping service.

\subsection{Wider system and decarbonisation drivers}

From whatever perspective shipping and climate change is viewed from, there is fundamental change on the horizon for the global shipping system. It is reasonable to anticipate, given the stringency of the language within the Paris Agreement, that additional policy mechanisms focused on decarbonising shipping will be required for the sector to fall into line with other countries' and sectors' commitments in the coming decade. For the sector to proactively meet the challenge, these policy measures must be connected to the required rate of decarbonisation. This special issue's publications also highlight the importance of policies that encourage innovation throughout the shipping system.

The shipping system will continually need to accommodate demand-side change, an aspect of the whole-system issue described in Walsh et al., 2016. Shipping is a service to other sectors, and so it will need to adjust to new patterns of economic growth and a strong decarbonisation agenda influencing fossil fuel trade, whilst at the same time dealing with its own climate challenges. Under such pressures, a re-evaluation of the likely future types 
and volumes of seaborne trade, and the routes navigable, is needed to estimate the extent of feasible technology change required to fit with the Paris Agreement. In addition to new climate drivers of trade and trading routes [1], any such re-evaluation also needs to consider shipping's role in the broader supply chain, in light of the persistence or otherwise of just-in-time delivery, differential costs of production and shifting consumer preferences across the world.

The feasibility of enabling radical improvements in ship system efficiency through, for example, the use of hub and spoke shipping systems (with the hubs served by much bigger ships), reduced ship speeds particularly for commodity trades, electric propulsion technologies, a move away from high carbon fossil fuels to lowcarbon energy systems, wind-assistance, new routes, voyage optimisation etc. requires further exploration. This will benefit from a whole-system perspective, complementing in-depth and focused research on any specific aspect. This is possible with the knowledge and tools available today, but will need financial or regulatory conditions to substantially change if they are to flourish.

\section{Conclusion}

There may be many stakeholders that choose to put their heads in the sand, and face a future where they are reacting to, rather than shaping change. On the other hand, for the smart stakeholders, the process of transition has already begun, and necessarily so, to avoid much larger, potentially disrupting or abrupt step changes later on [10]. Having long-term vision for investment to rapidly increase the number of higher efficiency ships on the high seas, coupled with supporting low-carbon fuel infrastructure, could also have co-benefits of mitigating other harmful pollutants. However, with so much uncertainty around technical performance, markets and finance, making bold policy or investment decisions can seem risky. Without knowledge which direction the sector should take towards decarbonisation (evidenced by the range of options within this special issue), decision making that can incorporate flexibility and adaptability is likely to be preferable to taking an optimisation approach.

All this points to the need for further work to explore and evaluate different future scenarios for shipping, and for those scenarios to be evaluated with a whole-system perspective. Such scenarios, when used to explore some of the directions the system could take and allowing for future shifts, are an essential supporting tool, offering an heuristic for difficult decision making. However, their plausibility is key - something that stakeholder engagement in any scenario building process can help with. Along with others in the academic community, the Shipping in Changing Climates consortium is taking such an approach, engaging with key industry and policy stakeholders around the economic, political and practical feasibility of whole-system change.
There are substantial challenges ahead for the shipping sector, and the policy making that will be needed to enable its decarbonisation. This opens up an opportunity for academia to contribute knowledge and analysis that can support this sector in contributing to the global challenge of avoiding dangerous climate change, whilst maximising shipping's continued contribution to global economic development.

\section{Acknowledgements}

This article and the papers referred to from this issue of Marine Policy were the outcome of the 4th International Conference on Low Carbon Shipping, 18-19 June 2014, in Liverpool, UK, organised as part of the Shipping in Changing Climates project (EP/K039253/ 1), funded by the Engineering and Physical Sciences Research Council (EP/K039253/1) as part of their Energy Programme.

\section{References}

[1] Y. Aksenov, E.E. Popova, A. Yool, A.J.G. Nurser, T.D. Williams, L. Bertino, J. Bergh, On the future navigability of Arctic sea routes: high-resolution projections of the Arctic Ocean and sea ice, Mar. Policy (2016).

[2] A. Bola, Potential for sustainable sea transport: a case study of the Southern Lomaiviti, Fiji islands, Mar. Policy (2016).

[3] A. Bows-Larkin S. Mander P. Gilbert M. Traut C. Walsh K. Anderson P. Stansby. High Seas High Stakes: High Seas Final Report. In: Tyndall Centre for Climate Change Research (Ed.). Tyndall Centre For Climate Change Research, 2014

[4] P. Deligiannis, Ship performance indicator, Mar. Policy (2016).

[5] P. Fenton, The role of port cities and transnational municipal networks in efforts to reduce greenhouse gas emissions on land and at sea from shipping an assessment of the World Ports Climate Initiative, Mar. Policy (2016).

[6] P. Gilbert, A. Bows, Exploring the scope for complementary sub-global policy to mitigate $\mathrm{CO}_{2}$ from shipping, Energy Policy 50 (2012) 613-622.

[7] P. Gilbert, P. Wilson, C. Walsh, P. Hodgson, The role of material efficiency to reduce $\mathrm{CO}_{2}$ emissions during ship manufacture: a life cycle approach, Mar. Policy (2016).

[8] IPCC, Climate Change 2013: The Physical Science Basis, Contribution of Working Group I to the Fifth Assessment Report of the Intergovernmental Panel on Climate Change, Cambridge, Cambridge University Press, UK and New York, NY, USA, 2013.

[9] A.M. Kotrikla, T. Lilas, N. Nikitakos, Abatement of air pollution at an aegean island port utilizing shore side electricity and renewable energy, Mar. Policy (2016).

[10] S. Mander, Slow steaming and a new dawn for wind propulsion: a multi-level analysis of two low carbon shipping transitions, Mar. Policy (2016).

[11] A. Newell, P. Nuttall, B. Prasad, J. Veitayaki, Turning the Tide: the need for sustainable sea transport in the Pacific, Mar. Policy (2016).

[12] N. Rehmatulla, S. Parker, T. Smith, V. Stulgis, Wind technologies: opportunities and barriers to a low carbon shipping industry, Mar. Policy (2016).

[13] N. Rehmatulla, T. Smith, L. Tibbles, The relationship between EU's public procurement policies and energy efficiency of ferries in the EU, Mar. Policy (2016).

[14] S. Suárez de la Fuente, D. Roberge, A.R. Greig, Safety and $\mathrm{CO}_{2}$ emissions: implications of using organic fluids in a ship's waste heat recovery system, Mar. Policy (2016).

[15] UNFCCC. Adoption of the Paris Agreement, Switzerland, 2015. 〈http://unfccc int/resource/docs/2015/cop21/eng/109r01.pdf). 